IZA DP No. 6284

Who Benefits from Benefits?

Empirical Research on Tangible Incentives

Andrea Hammermann

Alwine Mohnen

January 2012 


\title{
Who Benefits from Benefits? Empirical Research on Tangible Incentives
}

\author{
Andrea Hammermann \\ RWTH Aachen University \\ Alwine Mohnen \\ Technische Universität München \\ and IZA
}

\author{
Discussion Paper No. 6284 \\ January 2012
}

\author{
IZA \\ P.O. Box 7240 \\ 53072 Bonn \\ Germany \\ Phone: +49-228-3894-0 \\ Fax: +49-228-3894-180 \\ E-mail: iza@iza.org
}

\begin{abstract}
Any opinions expressed here are those of the author(s) and not those of IZA. Research published in this series may include views on policy, but the institute itself takes no institutional policy positions.

The Institute for the Study of Labor (IZA) in Bonn is a local and virtual international research center and a place of communication between science, politics and business. IZA is an independent nonprofit organization supported by Deutsche Post Foundation. The center is associated with the University of Bonn and offers a stimulating research environment through its international network, workshops and conferences, data service, project support, research visits and doctoral program. IZA engages in (i) original and internationally competitive research in all fields of labor economics, (ii) development of policy concepts, and (iii) dissemination of research results and concepts to the interested public.
\end{abstract}

IZA Discussion Papers often represent preliminary work and are circulated to encourage discussion. Citation of such a paper should account for its provisional character. A revised version may be available directly from the author. 


\section{ABSTRACT Who Benefits from Benefits?
Empirical Research on Tangible Incentives}

Although a broad field of literature on incentive theory exists, employer-provided tangible goods (hereafter called benefits) have so far been neglected by economic research. A remarkable exception is an empirical study by Oyer (2008). In our study, we test some of his findings by drawing on a German data set. We use two waves of the GSOEP data (2006, 2008) to analyze the occurrence of benefits and their effects on employees' satisfaction. Our results provide evidence for economic as well as psychological explanations. Looking at differences in firms' and employees' characteristics we find that cost efficiency concerns, the purpose to signal good working conditions and the aim to ease employees' effort costs are evident reasons to provide benefits. Furthermore, analyzing the impact of tangible and monetary incentives on satisfaction and employees' feeling of being acknowledged by employers, we find different motivational effects. Our results support the psychological explanation that benefits are evaluated separately from other monetary wage components and are more likely to express employers' concern for their employees and recognition of their performance.

JEL Classification: C83, J32, M52

Keywords: nonmonetary incentives, benefits, work motivation

Corresponding author:

Andrea Hammermann

RWTH Aachen University

Chair of Corporate and Human Resource Management

Templergraben 64

52056 Aachen

Germany

E-mail: Andrea.Hammermann@chr.rwth-aachen.de 


\section{Introduction}

The economic literature has, over a long time, focused extensively on incentive theory, and there are good reasons why the impacts of incentives are being investigated in such detail (for an overview, see Lazear and Oyer (2007)). Incentives help to overcome agency problems under asymmetric information and make relationships between employees and employers work more effectively. Whereas previous work almost exclusively focused on monetary incentives, a growing number of researchers are currently advocating a shift of focus to the hitherto neglected nonmonetary incentives (Ellingsen and Johannesson (2007)). Even when we keep in mind that money is the best metric and superior to any other form of payment due to its option value, practical evidence shows that it is far from being the only incentive used in work relationships (Lazear (1998)). In the following, we use the terms benefits and perks as synonyms for employer-provided, tangible goods which are given to employees in addition to monetary components of compensation. In our study, we test hypotheses in light of economic as well as psychological approaches to explain why tangible benefits are used and which impact they might have on employees' feeling of being acknowledged as well as on their work and wage satisfaction.

In the first part of this paper (Sections 2.1-2.3 and Section 4.1), we analyze the differences in benefit dispersions between branches, firms, and employees. According to Marino and Zábojník (2008), perks have a dual role because besides being used in productivity enhancement, they are also consumption goods which might be easily misused and, as a result, widen the scope of agency problems. Even if these concerns are certainly justified in some cases, Rajan and Wulf (2006) find no hints of a systematic misuse of perks in the empirical data of 300 publicly traded U.S. firms. Nevertheless, 
studies, such as the analysis of Hamermesh (1999), show that if people talk about earnings inequality, they often focus exclusively on monetary earnings, ignoring working conditions and misjudging wage gaps. In view of this finding, tangible compensation components could be used to conceal the true amount of earnings.

In his study, Oyer (2008) focuses on economic, rational, and efficient motives of employers to offer benefits instead of money. As a rule, the value and costs of benefits are not congruent, and both depend on certain personal as well as organizational characteristics. Thus, in line with Oyer (2008), our analysis tries to shed light on the following three hypotheses. First, cost-efficiency of benefits is a result of tax advantages (Grubb and Oyer (2008)) or economies of scale of firms compared to individual employees. In addition, benefits can be used to reduce wage rigidity in periods of recession when salaries are protected by contracts and unions (Oyer (2005)). Second, besides the advantages of lower costs of provision, benefits are also designed to attract target employees to companies. The reverse signaling approach by Backes-Gellner and Tuor (2010) points out that observable company characteristics are used as signals for unobservable characteristics, such as good work atmosphere or career prospects, to attract suitable applicants. Benefits are particularly apt to serve as signals because of their high observability. Third, benefits are chosen with a view to easing employees' effort costs, e.g., offering meals or child care close to the workplace to save time (Oyer (2008)).

In the second part of this paper (Section 2.4 and Sections 4.2-4.3), we closely analyze the effects of benefits. While salary is considered by many as an inappropriate conversation topic in Europe, a firm car or mobile phone is not because these are more visible to others and point out the performance of employees to insiders and outsiders of the firm. Therefore, benefits are more suitable as rewards for extraordinary performance or in 
relation to employees' status. According to the mental accounting theory by Thaler (1999), employees classify different salary components separately. Jeffrey and Shaffer (2007) argue that a pay rise does not have the same motivational effect as an equivalent benefit because of declining marginal utilities of additional earnings, whereas benefits are evaluated in isolation. They also assume that pecuniary incentives do not discourage employees for whom the benefit is out of reach because its value is subjective and can therefore be mentally adjusted. This is not possible when a prize has a monetary and therefore clearly objective value. Heyman and Ariely's experimental results (2004) point in the same direction. Their explanation is a discriminating perception of actions in social versus money markets. Money affects employees’ perception of acting in accordance with social norms in such a way that it becomes a factor in a simple cost-benefit analysis. However, benefits are, as might be expected, closer to gifts and tend to be seen as acts of kindness without shifting the perception of actions. To empirically address the question of different motivational consequences of monetary and tangible incentives, we analyze their impact as reflected in a wide range of statements by employees about recognition, as well as work and wage satisfaction. Incentive theory frequently concentrates on work satisfaction (see, e.g., Grund and Sliwka (2007)). According to Bewley (2004), satisfaction reflects three aspects of work morale, which are (1) firm identification, (2) positive reciprocity between employer and employee, and (3) the motivation to exert high work effort. Hence, if tangible incentives affect employees' satisfaction in a different way compared to money, this is important for employers when deciding about wage compositions.

To test reasons for benefit usage and its effect, we use data of the German SocioEconomic Panel (GSOEP). The GSOEP provides a representative sample of German 
households, including facts about employees as well as their employers. A question about perceived benefits asked in the wave 2006 and 2008 produced 18,044 observations. The results of this study support efficiency concerns as well as psychological explanations for benefit usage. Furthermore, we give evidence for a positive effect of benefits on work and wage satisfaction as well as employees' feeling of appropriate recognition. In particular, benefits seem suitable to reward good work performance and to show concern for employees’ well-being at the workplace.

The structure of our paper is as follows. In the next section, we introduce three hypotheses regarding differences in benefits' prevalence being dependent on firms' and employees' characteristics as well as two hypotheses about the effects of benefits. This is followed by a presentation of our data set as well as our key results in Sections 3 and 4 . The paper concludes with a summary in Section 5.

\section{Hypotheses}

\subsection{Cost-Efficiency Hypotheses}

When employers consider offering benefits, one crucial point are the costs of their provision. With regard to efficiency, benefits should bring cost advantages in comparison to a monetary salary increase. Cost-efficiency resulting from tax advantages cannot be addressed empirically in this study, due to lack of data. The consequences of adjustments in legislation concerning different taxation treatments of individuals and firms have, for instance, been analyzed by Grubb and Oyer (2008). Oyer (2008) has, theoretically and empirically, analyzed two main other reasons for a comparative advantage of providing tangible incentives. On the one hand, larger firms obtain goods generally at lower costs because of economies of scale effects. On the other hand, they are able to provide goods 
of their own branch of industry at cost of manufacture. For instance, firms in the automotive industry are in a better position, due to the lower costs involved, to offer cars as benefits. Moreover, by offering cars to their employees they increase the market share of the company. According to findings by Oyer (2008) on the relevance of firm size and branch of industry, we state the first two hypotheses:

H1a: Larger firms offer more benefits to employees because of economies of scale.

H1b: Firms are more likely to offer benefits related to their industries resulting from cost advantages of provision.

Nevertheless, financial aspects are far from being the only reason to use firm products as salary add-ons. Immaterial effects, such as developing firm identity and forming a specific employer branding, also have to be taken into account, as we will set out below.

\subsection{Sorting Hypotheses}

Building an authentic firm identity using observable benefits as signals can reduce mismatching as well as job vacancies as employees sort themselves into the most attractive firms according to their preferences (Backes-Gellner and Tuor (2010), Lazear (1998)). For instance, by offering sponsored meals or sports activities, firms send out signals of a pleasant work environment. Furthermore, fancy benefits can be part of a marketing strategy to increase the pool of applicants and, if these are related to the firm's product, they can also attract employees with a high affinity to a specific branch. One prominent example is the broad spectrum of rewards such as luxury travel trips, jewelry, 
and the famous pink Cadillac of Mary Kay. Spending more than \$50 million worldwide on rewards per year, the company has one of the most generous rewards and recognition programs in the direct selling industry. All benefits are extraordinary, luxurious, and have a female touch in line with the firm's image (Mary Kay Homepage (Accessed 10 November 2011)). Following the argument that employees sort themselves into different jobs, we predict that the prevalence of benefits will not only vary with firm characteristics but also with the personal characteristics of employees such as gender, marital status, and risk aversion. Over a long time, sex segregation based on different underlying preferences has been the subject of sociological analysis (Reskin (1993)), which has identified it as one of the most important explanations for a lower average wage of women. A study by Ferriman et al. (2009) provides evidence of different job choices of men and women based on differences in lifestyle preferences, the search for prestige as well as a consideration of the "gender type" of the chosen career. Hence we assume that men sort themselves into jobs and companies offering benefits because these might serve as status symbols. Instead, women are generally more family-oriented and decide in favor of a safe income rather than status symbols.

H2a: Men are more status seeking than women and therefore sort themselves into firms offering benefits as status symbols.

We also believe that marital status has an impact on the valuation of different benefits. If a person's life situation changes over time, his needs might shift as well, which would obviously apply to benefits such as child care. In accordance with empirical results by 
Oyer (2008), we predict that an employee's status 'married with children' is negatively related to benefits in the form of employer-provided meals.

H2b: Employees who are married and/or have children prefer eating at home rather than using the firm canteen.

Several empirical studies have shown that employers refrain from cutting nominal wages even in commercial crises to avoid negative effects on employees' motivation (Smith (2011)). The decline in motivation is based on loss aversion (Kahneman and Tversky (1979)), which has been found in various experiments (e.g., Kube et al. (2010)). Oyer (2005) argues in his paper that one reason for providing benefits is nominal wage rigidity. If reservation wages drop, it may be easier to abolish benefits than reduce nominal wages. We therefore argue that mainly volatile branches use benefits to maintain their wage flexibility and, as a result, risk seeking applicants select themselves into this kind of jobs (as has been shown by Cornelissen et al. (in press) with regard to performance pay).

H2c: Risk seeking employees select themselves into industries posing a higher risk regarding wages. Because of wage rigidity the firms in those industries tend to use benefits as compensation components that can be more easily cut back in times of recession.

\subsection{Effort Costs Hypothesis and Status Concerns}

The idea of a strict separation of home and office is affected by technological possibilities and an increasing demand of employees for flexible working hours. Flextime is thought 
to enhance the compatibility of career and family life and has become more important for job choices of the current generation (Smith (2010)). Certain benefits, such as child care or firm cars, might be used to signal the company’s desire to ease employees’ effort costs. Because productivity is unequal between the workforce, it might be more efficient to ease the effort costs of top performers who have a tough time schedule and high range of responsibilities (Rajan and Wulf (2006)).

H3a: Firms use benefits to reduce effort costs and offer these especially to highly productive and stressed-out employees to save them time to concentrate on more productive tasks.

Another argument by Rajan and Wulf (2006), also related to the reduction of effort costs, is that benefits are also apt to reward hard-working employees for the purpose of disclosing their high status to in- and outsiders of the firm. Hence, CEOs and managers with leading responsibilities who represent the firm and whose working time is of great importance to the overall firm performance are the most likely employees to get perks. Besides, perks perceived by firm leaders typically are valuable signals to convey high status, and, as a result, the desirability of perks increases when CEOs receive them.

H3b: Managers receive the most benefits because they occupy the top hierarchy levels and represent the company and spending less of their time on less productive tasks is in the firm's best interest. 


\subsection{Motivational Effects of Benefits}

The different consequences of monetary incentives have been analyzed at length in their various forms such as fixed pay, piece rates, bonuses, team based or individual (Lazear and Oyer (2007)). One reason why benefits have been neglected for so long is their varying value, which depends on employees’ preferences, whereas money seems superior due to its option value. Nevertheless, some economists, such as Jeffrey and Shaffer (2007), argue in favor of benefits based on a more emotional evaluation of material goods. To take a closer look at the different motivational effects of monetary and material incentives, we test these incentive effects on work and wage satisfaction and on different dimensions of recognition.

In employer-employee relationships, just as in any other social relationship, money might offend the recipient, if his motivation happens to be intrinsic (Frey (1997)). Based on a study of blood donations by Lacetera and Macis (2010), evidence was found that benefits were a better way to acknowledge desired behavior without reducing intrinsic motivation. However, benefits effectively enhance motivation only if they fit the preferences of employees. Moreover, similar to nonmonetary gifts, benefits could signal the donor's degree of information concerning the recipient's preferences (Prendergast and Stole (2001)). As an additional value of the objective price of benefits, employees appreciate the searching costs of employers to find the right incentives. Additionally, due to the fact that nonmonetary incentives are generally scarce resources and observable by others, as mentioned above, they are suitable to be offered as special rewards for good performance, showing employer's respect and employee’s status (Ellingsen and Johannesson (2007)). In summary, employees who receive benefits feel acknowledged. A feeling which might 
not be induced to the same extent by a rather anonymous and impersonal monetary salary.

H4: Benefits reflect an acknowledgment of employees' work and consequently have a positive impact on their feeling of being acknowledged.

Also, according to a psychological approach by Jeffrey and Shaffer (2007), employees mentally segregate or aggregate different subsets of income to different mental accounts. Based on the assumption of mental accounting (Thaler (1999)), benefits should have a higher incentive impact than a monetary pay rise. The reason is that benefits go into a separate mental account and consequently do not have the declining marginal utility of additional monetary earnings.

H5: An employee gains less satisfaction from additional monetary payments compared to tangible incentives due to separability effects of mental accounting.

\section{Data Set}

We use the waves 2006 and 2008 of the German Socio-Economic Panel (GSOEP). ${ }^{1}$ The GSOEP is a repetitive panel survey of German households (for further details on this data

\footnotetext{
${ }^{1}$ The data used in this paper were extracted using the Add-On package PanelWhiz v3.0 (Nov 2010) for Stata. PanelWhiz was written by Dr. John P. Haisken-DeNew (john@panelwhiz.eu). The PanelWhiz generated DO file to retrieve the SOEP data used here, and any PanelWhiz Plugins are available upon request. Any data or computational errors in this paper are our own. Haisken-DeNew and Hahn (2006) describe PanelWhiz in detail.
} 
set, see Wagner et al. (1993)). Exclusively, in 2006 and 2008, a question about employerprovided benefits is included. ${ }^{2}$ While we do not have any data about costs and appearance of the benefits provided, we limit our analysis to the probability of their existence, based on the heterogeneity across firms and employees.

We concentrate on full-time and part-time employees in blue- or white-collar positions as well as employees with managerial responsibilities. A common employer-employee relationship is essential to interpret the intentions behind benefits and their effects. Therefore, self-employed people, interns, and trainees as well as civil servants are excluded for reasons of comparison. In total, that leaves us with an unbalanced panel with 18,044 observations of 11,100 subjects. The average subject is 42 years old with around 17 years of job experience and 12 years of education. Fifty percent of all subjects are male, and around $62 \%$ are married. For an overview of descriptive statistics, see Table A1 (in the Appendix). The benefit variables are dummies with the value of one if the subject questioned is quoted as receiving such a benefit from his employer. In this paper, we focus on five different benefits: employer-provided meals (meal), firm cars, phones or PCs for private usage, and expense payments above the minimum costs (expenses). All these benefits are provided in material rather than monetary form.

\footnotetext{
${ }^{2}$ Do you receive other benefits from your employer besides your pay? (Dummy variables). Discounted lunch in the company lunchroom or a meal stipend (meal); company vehicle for private use (car); cellular phone for personal use, or reimbursement of telephone costs (phone); expense payments covering more than minimum costs (expenses); personal computer or laptop for use at home (PC).
} 


\section{Figure 1: Occurrence of benefits in 2006 and 2008}

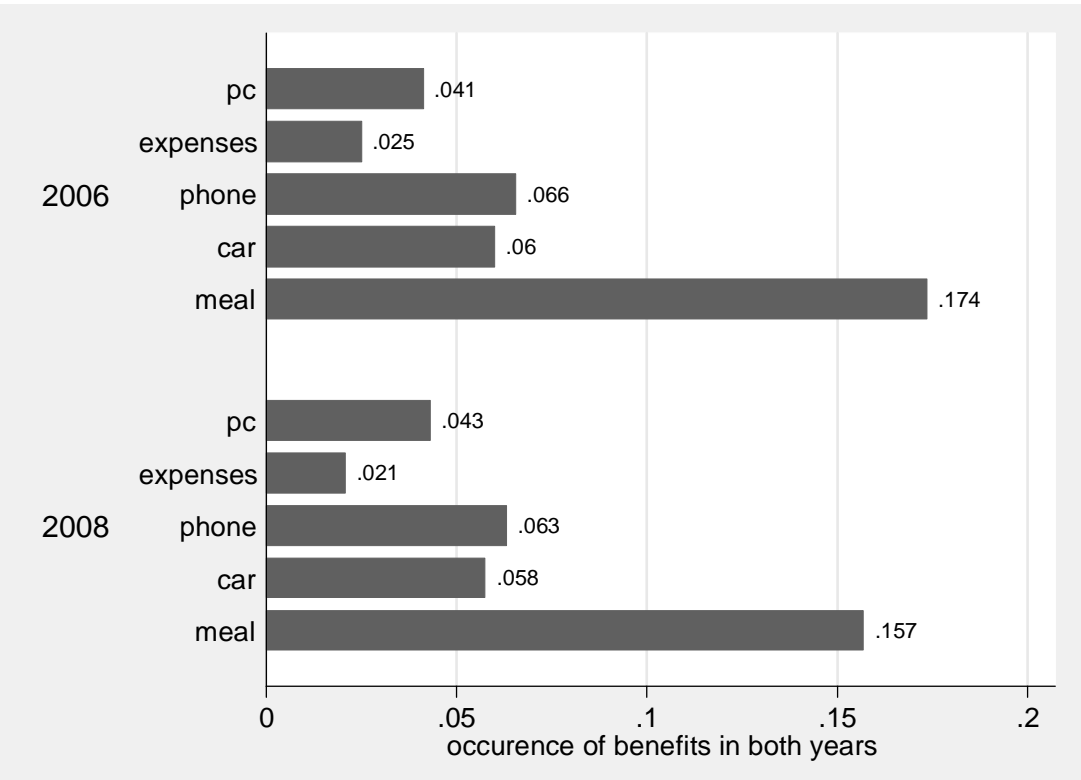

Figure 1 shows the occurrence of all five benefits separately for 2006 and 2008. Meals are by far the most frequently perceived benefits. Thus, firm cars and phones are perceived by around $6 \%$ of subjects questioned, followed by PCs with $4 \%$. Expense payments above the minimum costs are rarely mentioned as perceived benefits (by $2.1 \%$ to $2.5 \%$ ). As can be seen, no big differences exist between the average benefit perception for the two years except the decline in meals as perceived benefits by 1.7 percentage points from $17.4 \%$ in 2006 to $15.7 \%$ in 2008 . The difference in average benefit perception is significantly lower in 2008 but only for meals $(\mathrm{p}=0.003)$ and expenses $(\mathrm{p}=0.061)$, according to a two-sided t-test. In contrast, no significant difference in monetary bonuses $(\mathrm{p}=0.486)$ and gross wages $(\mathrm{p}=0.271)$ could be found. Given that 2008 was the beginning of the worldwide financial crisis, this could be a first hint of benefit reduction in recessions to reduce nominal wage rigidity. 
Figure 2: Occurrence of benefits distinguished by different firm sizes

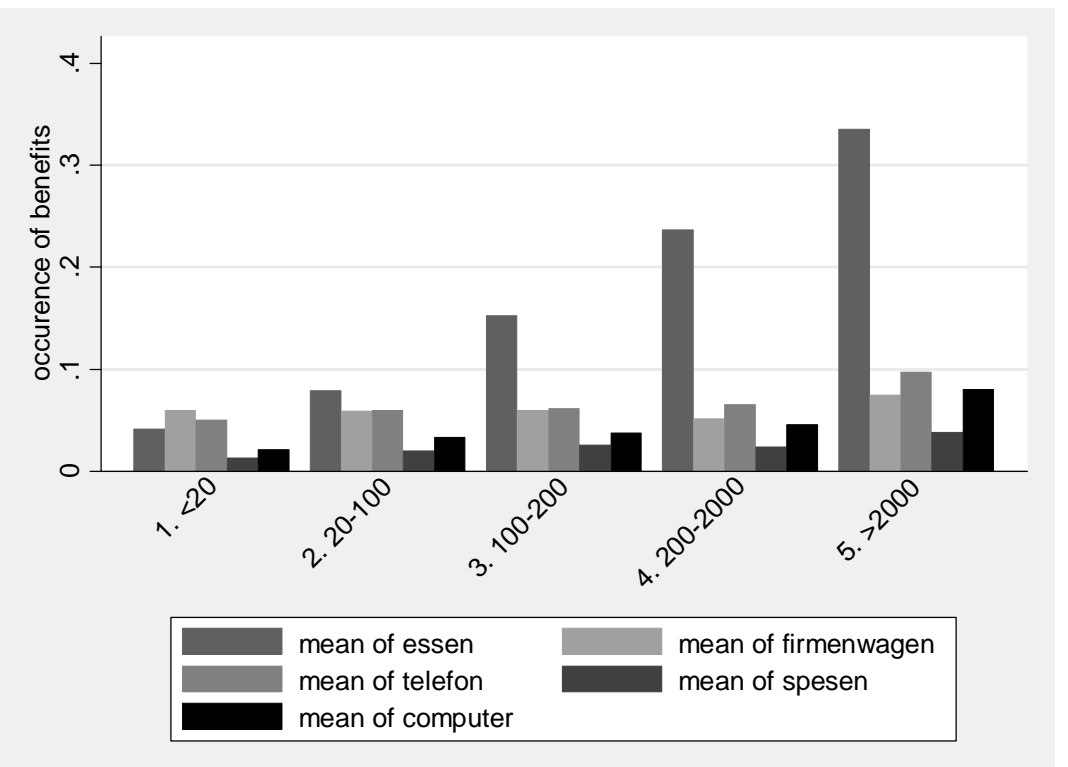

When we use the number of employees as a proxy for firm size (see Fig. 2), we observe that large companies use benefits as incentives more often than small and medium sized enterprises (SME), defined by us as companies with less than 200 employees (according to the EU definition of small and middle sized enterprises ( $<250$ employees)). The higher frequency of employees receiving benefits in large firms compared to SMEs is statistically significant on the $1 \%$ level for all benefits, based on a two-sided t-test. The only exceptions are firm cars, for which no statistically significant difference with regard to company size can be found. Based on economies of scale considerations, the higher frequency of benefits in large firms is reasonable.

Finally, taking a closer look at the employees in a company who were more likely to receive benefits, we concentrated on three different job classifications. Figure 3 shows the average hours worked overtime separately for blue- and white-collar staff and managers, for employees who received at least one benefit, and those who did not receive any benefits. According to a two-sided t-test, the difference in overtime work is 
significantly higher $(\mathrm{p}=0.000)$ for employees on each hierarchy level if they received at least one nonmonetary benefit. A positive relationship between working overtime and receiving benefits can thus be reported. In the next section, we check the robustness of our hypotheses with a multivariate analysis.

Figure 3: The average number of hours worked overtime per week

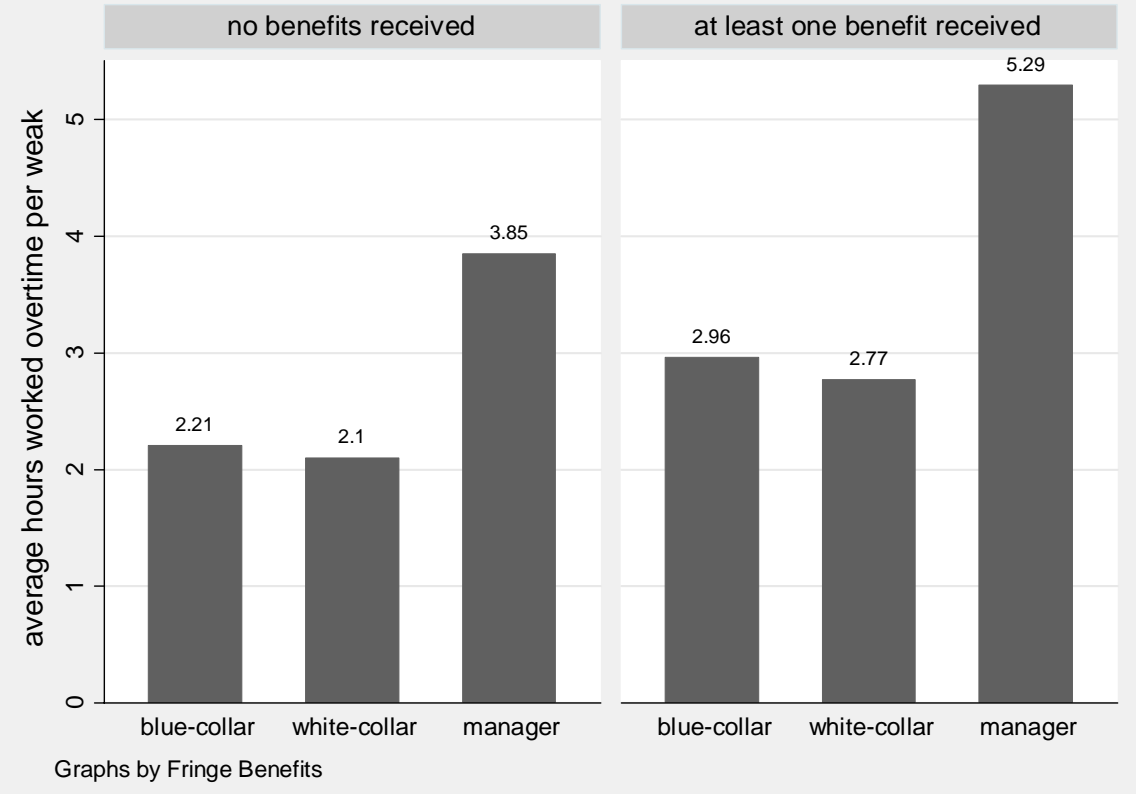

\section{Results}

\subsection{The Probability of Receiving Benefits Based on Personal, Job, and Organizational Characteristics}

We ran a random effects probit regression to determine whether benefits were used rationally according to our hypotheses. We used random instead of fixed effects models because we are interested in explanatory effects of time-invariant variables and fixed effects probit models are impossible to compute. Because of missing data of our explanatory variables, our sample was reduced to 10,970 observations of 6,631 subjects. 
The influence of certain explanatory variables on the probability of the five benefits is reported in Table A2 (in the Appendix). The dependent variable of the random effects regression in the first column is the number of perceived benefits (ranging from 0 to 6 ) as accumulation of the five named benefits and an option of "other benefits". However, the option "other benefits" is not analyzed any further because its interpretation is not clear. To check for the robustness of our results, we ran a multinominal $\operatorname{logit}^{3}$ and a clustered OLS regression (not reported). Both econometric models support our key results, which we summarize below.

In line with Hypothesis 1a, small and middle sized firms offer significantly fewer benefits, in particular fewer meals. The positive economies of scale effects are quite evident regarding sponsored meals or the setting-up of a company-owned canteen, due to quantity discounts or high fixed costs. However, smaller firms use firm cars more often. This might be due to the need of small firms, for instance craftsmen or suppliers, to reach customers at their locations, or the fact that many small firms are located in rural areas. As for benefit-related branches, we find mixed results. Whereas there is a higher occurrence of meals in the food industry and phones and PCs in the IT industry, there is no significantly larger fraction of firms in the car industry providing firm cars. Two explanations are possible. First, as mentioned before, there might be a high need for cars in all branches of industry, but, given the data available, we are unable to distinguish between luxurious cars as status symbols and more practical cars. Second, cars are

\footnotetext{
${ }^{3}$ The multinomial logit regression is an extension of the logit model, allowing more than two discrete outcomes without a required order of the categorical dependent variable (for a short summary of the econometric methodology, see Constant and Zimmermann (2003)).
} 
considered important by Germans and are thus popular perks throughout all industries. In summary, our data provide evidence for hypotheses H1a and H1b concerning cost efficiency for employers of large firms and employers in benefit-related branches.

\section{Result 1: Small and middle sized firms provide fewer benefits, and those in benefit- related branches provide more benefits. However, predictions do not fit the provision of firm cars.}

In the following, we review the sorting of employees into jobs and branches offering specific benefits (Hypotheses 2a, 2b, 2c). First, female employees receive fewer benefits in terms of firm cars, phones, and expenses. As we controlled for hierarchy levels (manager, blue- or white-collar staff) and wages, this effect is not only explained by few female managers but also by women sorting themselves into jobs with fewer technical devices as status symbols and involving less job mobility. Second, married employees perceive employer-provided meals less often. The presence of children in the respective households seems to have no effect. But the dummy for at least one child in a household had a significantly negative influence on the probability of such employees receiving expenses when we used the clustered OLS or multinominal logit. Even if this effect is not robust for all models, it makes sense that parents avoid too much travel in order to spend more time with their children. Third, controlling for the risk aversion of employees, we find that those seeking more risk receive significantly more benefits such as phones, expenses, and PCs. Evidently, employees who are more risk tolerant sort themselves into jobs and branches that offer these benefits and accept that, as Oyer (2005) has shown, benefits are cut back in economic recessions. 


\section{Result 2: Gender, marital status, and risk aversion are characteristics which influence employees' job choice and lead to an unequal dispersion of benefit perception.}

To empirically prove Hypotheses $3 \mathrm{a}$ and $3 \mathrm{~b}$ regarding the reduction of effort costs by benefits, we use proxies for high performing employees as well as those with high workloads (proxies for human capital and workload are selected from former studies of SOEP data, e.g., Holst and Busch (2009); Cornelissen et al. (in press), and Dohmen et al. (2009)). To classify our subjects according to productivity, we use education as a proxy for general human capital and tenure as a proxy for specific human capital (for a theoretical analysis of human capital, see Becker (1962)). Tenure, as a measure of the years an employee has worked in a particular firm, has a significantly negative effect on the quantity of benefits, especially concerning firm cars, expenses, and PCs. This finding is unexpected as it seems to imply that less productive workers, in terms of specific human capital, receive more benefits. But this finding has to be interpreted with caution because no assessment regarding the quality of received benefits can be made. One explanation might be that older employees (with longer tenure) in our sample prefer money to the mostly technical benefits. Moreover, as material benefits have become more popular in recent years, they may not have been included in the contracts of older employees. Dummies for educational qualifications show the predicted influences. Employees with an upper secondary leaving certificate receive more benefits, especially PCs, and those with a secondary general school leaving certificate or other school leaving certificate receive fewer benefits than the reference group with an intermediate school 
leaving certificate (for an overview about the German school system see Heineck and Wölfel (2010)). As a consequence, we conclude that a higher general human capital, measured in terms of school qualifications provides a better chance of receiving benefits of the kind mentioned in the GSOEP. In contrast, more job experience has no effect in this respect.

In the context of the second part of Hypothesis 3a, we examine the working stress of employees, measured in terms of average hours worked overtime per week, and of parttime employees who often have another job or obligation as well. With the exception of employer-provided meals, employees who invest more time at work are more likely to receive benefits. Furthermore, part-time employees receive a greater quantity of benefits. This effect is based on "other benefits," which are more likely received by part-time employees. Even if we can only speculate about the nature of these benefits, child care might be among them. It would be logical to assume that institutions which offer parttime jobs, such as universities, emphasize arrangements to improve work-life balances. In accordance with Hypothesis 3b, status also plays a crucial role in benefit perception. Managers are more and blue-collar workers less likely to be offered firm cars, phones, and PCs than white-collar workers without leading responsibilities. The absent significance and negative sign of 'employer-provided meals' are plausible because top managers are more often en route or have dinner with clients than employees on lower hierarchy levels. In addition, the dummy for job promotion (measured by an anticipated job promotion in the next two years, asked in 2005) has a highly significantly positive effect on all five benefits.

These results indicate that employees on higher hierarchy levels are more likely to receive benefits. However, the intentions that play a role in these results are impossible to 
disentangle because they would be a mix of status revealing effort cost reduction. The latter resulting from managers are in general the most productive ones in a firm, making the reduction of effort costs highly efficient. The fact that benefits are not simply used as a substitute for monetary compensation components is shown by the positive impact of income and monetary bonuses on benefit perception. The question arises whether money and benefits are complementary rather than substitutional. As we did not observe the entire salary package in all instances, the results may be biased by underlying but unobserved characteristics, such as ability, which correlates with wage and affect benefit reception. The question can therefore not be satisfactorily answered by our analysis. However, the notion of money and benefit as complements is plausible because tax progression may lead to a higher profitability of material salary components for highly salaried employees.

\section{Result 3: Top performers with higher school qualifications, employees with a higher workload, and managers representing the firm receive benefits more often.}

Finally, the year dummy for 2006 is significantly positive, meaning that employerprovided meals have been cut back in the period 2006 to 2008. This results support our findings in descriptive statistics.

\subsection{Effects of Benefits on the Feeling of Being Acknowledged}

To test the effect of monetary and nonmonetary incentives on the feeling of being acknowledged, we ran four probit regressions. Unfortunately, it was not possible to refer 
to panel data because the question was only included in the 2006 questionnaire. The binary dependent variables are agreement (Dummy variables equal 1) or disagreement on statements of different dimensions of recognition. ${ }^{4}$ Hypothesis 4 predicts positive signs for benefit coefficients, whereas money should not have such a concise effect. Table A3 in the Appendix displays our results. For nonmonetary incentives we included the five benefits in our regressions, while for monetary incentives we used the logarithms of income and the sum of monetary bonuses (money). ${ }^{5}$

Employer-provided meals have a significantly positive effect on employees' feeling of deserved recognition by superiors and having personal advancement opportunities. The latter is also positively influenced by firm cars. Phones and monetary bonuses enhance the employee's satisfaction with his performance, which is acknowledged in this way. Income has only a significant effect on the feeling of being paid an adequate wage and having personal advancement opportunities. With the exception of expenses and PCs, which have no effect or, in case of PCs, even a negative effect on adequate wages, benefits enhance the feeling of being acknowledged in all four dimensions. Whereas employer-provided meals seem to contribute to a feeling that a firm cares about their

\footnotetext{
${ }^{4}$ Agreement or Disagreement to the following statements (Dummy variables):

I receive the recognition I deserve from my superiors. (recog_superior); When I consider all my accomplishments and efforts, the recognition I've received seems fitting. (recog_performance); When I consider all my accomplishments and efforts, my chances of personal advancement seem fitting. (recog_career); When I think about all my accomplishments, my pay seems appropriate. (recog_wage).

${ }^{5}$ Variable "money" equals the sum of the following additional gross payments in the previous year if employee has not changed her workplace in 2005: 13th, 14th month salary, additional Christmas bonus, vacation pay, profit-sharing bonuses or other bonuses.
} 
employees' well-being, phones and firm cars are more representative and are perceived as status symbols for high performers with good career opportunities. Even if the intentions behind benefits could not be directly analyzed in our study, the results show a broad impact of benefits on the feeling of being acknowledged.

\section{Result 4: High income is not sufficient to address employees' need to be acknowledged. Benefits are suitable, in particular, to reward the good performance of top performers and to show concern for employees' well- being.}

Further to Result 4, we want to add some remarks on the effects of our control variables. Age as well as job tenure have a negative influence on employees' satisfaction with the recognition received. Employees who work more overtime and have a longer education (in years) are also less satisfied. A decline in job satisfaction in conjunction with higher job tenure in general has been found by other authors as well (Grund and Sliwka (2007)). This could be due to employees' increased demand for recognition because they dedicate more time to a specific company. Generally, more investment in education and higher work performance also raise hopes for recognition and that effort should pay off. Evidently, this cannot be adequately addressed by employers. The most satisfied are managers and part-time employees working in Western Germany and those who have no worries about the security of their jobs. 


\subsection{Effects of Benefits on Work and Wage Satisfaction}

We used fixed effect models to test the influence of benefits on work and wage satisfaction. Results are displayed in Table A4 in the Appendix. First of all, it is obvious that income has a highly significantly positive effect on wage and job satisfaction. This resembles results for absolute income effects by Grund and Sliwka (2007). Moreover, employees who receive at least one benefit are more satisfied with their job and income (effect on income is only near the $10 \%$ level in model four). In contrast, the sum of monetary bonuses has no significant effects even if the t-value is close to the $10 \%$ level for wage satisfaction. The monetary bonuses were 2,110.89 euros in 2006 and 2,177.26 euros in 2008. The medians are much smaller with 980 and 800, respectively. Obviously, the bonus payments were far from being negligible. Therefore, it is quite surprising that they do not have any effect on work satisfaction, thus supporting Hypothesis 5 in that additional monetary payments are not regarded in the same way as nonmonetary compensation components and are simply added to the income already received. The advantage of benefits, instead, is that employees tend to evaluate them in isolation and often with emotional involvement, as discussed in Jeffrey and Shaffer (2007). That benefits lead to an increase in work satisfaction is shown by experimental evidence on the effect on work performance by Kube et al. (in press) or Jeffrey (2009).

\section{Result 5: Besides income, benefits tend to increase work satisfaction. This positive effect is not found for monetary bonuses.}

\section{Discussion and Conclusion}

Using a large German data set, we revise empirical findings by an U.S. study of Oyer (2008) on the probability of benefit perception with regard to personnel and company 
characteristics. We also extend the existing literature by focusing on how benefits affect employees' feeling of being acknowledged as well as their work and wage satisfaction. To our knowledge, the rare literature on the effects of benefits has until now mainly concentrated on experimental findings (Kube et al. (in press) or Jeffrey (2009)). Hence, the higher degree of heterogeneity in our subject pool allows us to address the subject of effects on a broader basis. First, our results suggest that benefits are used efficiently, aiming to attract the right employees, enhance their work satisfaction, and ease their effort costs. Consequently, this study gives evidence that the aforementioned rational intentions behind offering benefits, as discussed in the U.S. studies, also apply to German labor markets. Second, benefits increase work and wage satisfaction and seem to contribute to a work atmosphere in which an employee feels his work is acknowledged by superiors.

However, we are aware of some limitations of our data set. First and foremost, it is unfortunately not possible to distinguish between luxurious benefits and benefits offered for a more practical use because no figures are given on their value. In addition, the question regarding benefit reception was only included in two waves, and only one wave also contained a set of questions about the feeling of being acknowledged. Therefore, further research on employer-provided benefits is recommended. For one thing, it would be worthwhile to use firm data rather than the self-reported facts of a survey, which would yield new insights in the intentions of employers and the structures used within firms. In addition, information about the appearance and price of benefits is needed to test, in more detail, hypotheses on the trade-off between money and benefits. Because of an increase in popularity of nonmonetary compensation components, the intentions behind benefit usage and its actual effects on job attraction, satisfaction, work 
performance, and retention management should also be elaborated. Another pertinent research question would be whether benefits really ease work effort costs or might even increase working stress because with work flexibility, employees' accessibility increases as well. But a deeper preoccupation with tangible incentives is recommended not only for academic researchers but also for practitioners. The various functions of tangible benefits, either as status symbols or gifts, influence the work atmosphere. Practitioners can, for instance, choose an amiable workplace by offering employer-provided meals or create an environment of competition among employees about the scarce resources of a firm like parking spaces and corner offices.

\section{Acknowledgment}

We would like to thank Anastasia Danilov and participants of the Tinbergen Institute/ZEW Conference (2010) in Rotterdam and the 14. Kolloquium zur Personalökonomie (2011) in Zurich for valuable remarks which have helped to improve our work. All errors are our own. 


\section{References}

Backes-Gellner, U., Tuor, S.N. (2010): Avoiding labor shortages by employer signaling: on the importance of good work climate and labor relations. Industrial and Labor Relations Review 63 (2), pp. 271-286.

Becker, G.S. (1962): Investment in human capital: A theoretical analysis. Journal of Political Economy 70 (5), pp. 9-49.

Bewley, T. (2004): Fairness, reciprocity, and wage rigidity. IZA Discussion Papers 1137.

Constant, A., Zimmermann, K.F. (2003): Occupational choice across generations. Applied economics quarterly 49 (4), pp. 299-317.

Cornelissen, T., Heywood, J.S., Jorjahn, U. (in press): Performance Pay, Risk Attitudes and Job Satisfactions. Labor Economics.

Dohmen, T., Falk, A., Huffman, D., Sunde, U. (2009): Homo reciprocans: Survey evidence on behavioural outcomes. The Economic Journal 119 (536), pp. 592612.

Ellingsen, T., Johannesson, M. (2007): Paying respect. The Journal of Economic Perspectives 21 (4), pp. 135-149.

Ferriman, K., Lubinski, D., Benbow, C.P. (2009): Work preferences, life values, and personal views of top math/science graduate students and the profoundly gifted: Developmental changes and sex differences during young adulthood and parenthood. Journal of Personality and Social Psychology 97 (3), pp. 517-532.

Frey, B.S. (1997): Not just for the money: An economic theory of personal motivation. Edward Elgar Pub., Cheltenham, UK, Brookfield, Vt.

Grubb, M.D., Oyer, P. (2008): Who benefits from tax-advantaged employee benefits?: Evidence from university parking. NBER working paper series No. 14062.

Grund, C., Sliwka, D. (2007): Reference-dependent preferences and the impact of wage increases on job satisfaction: Theory and evidence. Journal of Institutional and Theoretical Economics 163 (2), pp. 313-335.

Haisken-DeNew, J.P., Hahn, M. (2006): PanelWhiz: A flexible modularized stata interface for accessing large scale panel data sets. http://panelwhiz.com/docs/PanelWhiz_Introduction.pdf.

Hamermesh, D.S. (1999): Changing inequality in markets for workplace amenities. The Quarterly Journal of Economics 114 (4), pp. 1085-1123.

Heineck, G., Wölfel, O. (2010): Parental risk attitudes and children's secondary school track choice. SOEPpapers 344.

Heyman, J., Ariely, D. (2004): Effort for payment. A tale of two markets. Psychological Science 15 (11), pp. 787-793.

Holst, E., Busch, A. (2009): Der „Gender Pay Gap“ in Führungspositionen der Privatwirtschaft in Deutschland. SOEPpapers 169. 
Jeffrey, S.A. (2009): Justifiability and the motivational power of tangible noncash incentives. Human Performance 22 (2), pp. 143-155.

Jeffrey, S.A., Shaffer, V. (2007): The motivational properties of tangible incentives. Compensation and Benefits Review 39 (3), pp. 44-50.

Kahneman, D., Tversky, A. (1979): Prospect theory: An analysis of decision under risk. Econometrica 47 (2), pp. 263-291.

Kube, S., Maréchal, M., Puppe, C. (in press): The currency of reciprocity-Gift-exchange in the workplace. The American Economic Review.

Kube, S., Maréchal, M.A., Puppe, C. (2010): Do wage cuts damage work morale?: Evidence from a natural field experiment. IEW Working Paper 471.

Lacetera, N., Macis, M. (2010): Do all material incentives for pro-social activities backfire? The response to cash and non-cash incentives for blood donations. Journal of Economic Psychology 31 (4), pp. 738-748.

Lazear, E. (1998): Personnel economics for managers. John Wiley \& Sons.

Lazear, E.P., Oyer, P.E. (2007): Personnel economics. NBER Working Paper No. 13480.

Marino, A.M., Zábojník, J. (2008): Work-related perks, agency problems, and optimal incentive contracts. The Rand Journal of Economics 39 (2), pp. 565-585.

Mary Kay Homepage: Rewards and Recognition site. http://www.marykay.com/sellmarykay/rewardrecognition/default.aspx. Accessed 10 November 2011.

Oyer, P.E. (2005): Can employee benefits ease the effects of nominal wage rigidity? Evidence from labor negotiations. Working Paper Stanford Graduate School of Business.

Oyer, P.E. (2008): Salary or Benefits? Research in Labor Economics 28, pp. 429-467.

Prendergast, C., Stole, L.A. (2001): The non-monetary nature of gifts. European Economic Review 45 (10), pp. 1793-1810.

Rajan, R., Wulf, J. (2006): Are perks purely managerial excess? Journal of Financial Economics 79, pp. 1-33.

Reskin, B.F. (1993): Sex segregation in the workplace. Annual Review of Sociology 19, pp. 241-270.

Smith, J.C. (2011): Pay Growth, Fairness and Job Satisfaction: Implications for Nominal and Real Wage Rigidity. Scandinavian Journal of Economics (provisionally accepted).

Smith, K.T. (2010): Work-life balance perspectives of future marketing professionals. Services Market Quarterly 31 (4), pp. 434-447.

Thaler, R.H. (1999): Mental Accounting Matters. Journal of Behavioral Decision Making 12, pp. 183-206. 
Wagner, G.G., Burkhauser, R.V., Behringer, F. (1993): The English Language Public Use File of the German Socio-Economic Panel. Journal of Human Resources 28 (2), pp. 429-433. 


\section{Appendix}

Table A1: Descriptive Statistics (GSOEP 2006 and 2008 if survey participant is white-collar, blue-collar, or manager)

\begin{tabular}{|c|c|c|c|c|c|c|}
\hline Variable & Description & Obs & Mean & Std. & Min & Max \\
\hline \multicolumn{7}{|c|}{ Organizational Characteristics } \\
\hline Sme & $\begin{array}{l}\text { Small and middle sized enterprises } \\
\text { Dummy }=1 \text { if company has less than } \\
200 \text { employees, } 0 \text { otherwise }\end{array}$ & 16,725 & 0.559 & 0.497 & 0 & 1 \\
\hline Food_industry & $\begin{array}{l}\text { Dummy }=1 \text { if company is in food } \\
\text { industry, } 0 \text { otherwise }\end{array}$ & 16,555 & 0.048 & 0.214 & 0 & 1 \\
\hline Car_industry & $\begin{array}{l}\text { Dummy= } 1 \text { if company is in car } \\
\text { industry, } 0 \text { otherwise }\end{array}$ & 16,555 & 0.035 & 0.183 & 0 & 1 \\
\hline IT_ industry & $\begin{array}{l}\text { Dummy= } 1 \text { if company is in IT } \\
\text { industry, } 0 \text { otherwise }\end{array}$ & 16,555 & 0.063 & 0.244 & 0 & 1 \\
\hline Western & $\begin{array}{l}\text { Dummy=1 if company location is in } \\
\text { Western Germany, } 0 \text { otherwise }\end{array}$ & 18,044 & 0.770 & 0.421 & 0 & 1 \\
\hline Works council & $\begin{array}{l}\text { Dummy }=1 \text { if a works council exists, } \\
0 \text { otherwise }\end{array}$ & 16,598 & 0.553 & 0.497 & 0 & 1 \\
\hline \multicolumn{7}{|c|}{$\underline{\text { Job Characteristics }}$} \\
\hline Blue-collar & $\begin{array}{l}\text { Dummy }=1 \text { if employee is a blue- } \\
\text { collar worker, } 0 \text { otherwise }\end{array}$ & 18,044 & 0.354 & 0.478 & 0 & 1 \\
\hline White-collar & $\begin{array}{l}\text { Dummy=1 if employee is a white- } \\
\text { collar worker, } 0 \text { otherwise } \\
\text { (Reference Group) }\end{array}$ & 18,044 & 0.446 & 0.497 & 0 & 1 \\
\hline Manager & $\begin{array}{l}\text { Dummy }=1 \text { if employee is a manager, } \\
0 \text { otherwise }\end{array}$ & 18,044 & 0.200 & 0.400 & 0 & 1 \\
\hline Prom & $\begin{array}{l}\text { Likelihood ( } 0 \%-100 \%) \text { of being } \\
\text { promoted in the next two years } \\
\text { (asked in 2005) }\end{array}$ & 13,857 & 17.312 & 23.893 & 0 & 100 \\
\hline Tenure & $\begin{array}{l}\text { Years employees have been staying } \\
\text { in the company }\end{array}$ & 18,022 & 10.863 & 9.722 & 0 & 57 \\
\hline Part-time & $\begin{array}{l}\text { Dummy= } 1 \text { if employee work part- } \\
\text { time, } 0 \text { otherwise }\end{array}$ & 16,370 & 0.235 & 0.424 & 0 & 1 \\
\hline Overtime & $\begin{array}{l}\text { Average hours worked overtime per } \\
\text { week }\end{array}$ & 17,537 & 2.346 & 3.673 & 0 & 23.1 \\
\hline Satwork & $\begin{array}{l}\text { Work satisfaction [0 dissatisfied } 10 \\
\text { satisfied] }\end{array}$ & 17,594 & 6.925 & 2.003 & 0 & 10 \\
\hline Satwage & $\begin{array}{l}\text { Wage satisfaction [0 dissatisfied } 10 \\
\text { satisfied] }\end{array}$ & 17,975 & 6.059 & 2.231 & 0 & 10 \\
\hline Recog_superior $^{a}$ & $\begin{array}{l}\text { Dummy=1 if employee feels } \\
\text { recognized by their superior, } 0 \\
\text { otherwise }\end{array}$ & 9,258 & 0.652 & 0.476 & 0 & 1 \\
\hline $\begin{array}{l}\text { Recog_- } \\
\text { performance }^{\mathrm{a}}\end{array}$ & $\begin{array}{l}\text { Dummy }=1 \text { if employee feels his } \\
\text { performance is acknowledged, } 0 \\
\text { otherwise }\end{array}$ & 9,254 & 0.650 & 0.477 & 0 & 1 \\
\hline Recog_career $^{\mathrm{a}}$ & $\begin{array}{l}\text { Dummy }=1 \text { if employee is satisfied } \\
\text { with his career prospects, } 0 \\
\text { otherwise }\end{array}$ & 9,107 & 0.604 & 0.489 & 0 & 1 \\
\hline Recog_wage $^{a}$ & $\begin{array}{l}\text { Dummy }=1 \text { if employee states his } \\
\text { wage to be adequate, } 0 \text { otherwise }\end{array}$ & 9,283 & 0.457 & 0.498 & 0 & 1 \\
\hline
\end{tabular}




\begin{tabular}{|c|c|c|c|c|c|c|}
\hline Variable & Description & Obs & Mean & Std. & Min & Max \\
\hline Job security & $\begin{array}{l}\text { Dummy= } 1 \text { if employee is not at all } \\
\text { concerned about his job security ( } 0 \text { if } \\
\text { employee is somewhat or very } \\
\text { concerned) }\end{array}$ & 17,512 & 0.407 & 0.491 & 0 & 1 \\
\hline Job change & $\begin{array}{l}\text { Dummy }==1 \text { if employee changed his } \\
\text { job or started a new one during the } \\
\text { previous year, } 0=\text { otherwise }\end{array}$ & 1804 & 0.175 & 0.380 & 0 & 1 \\
\hline \multicolumn{7}{|l|}{ Compensation } \\
\hline $\ln ($ income) & Logarithm of income before taxes & 18,002 & 7.478 & 0.863 & $\begin{array}{r}2.89 \\
0\end{array}$ & 10.309 \\
\hline Money_d $\mathrm{d}^{\mathrm{b}}$ & $\begin{array}{l}\text { Dummy= } 1 \text { if employee perceives } \\
\text { one or more monetary bonuses }\end{array}$ & 16,761 & 0.704 & 0.457 & 0 & 1 \\
\hline Money $^{\mathrm{b}}$ & $\begin{array}{l}\text { Sum of perceived monetary bonuses } \\
(€)\end{array}$ & 15,749 & $\begin{array}{r}2142.65 \\
5\end{array}$ & $\begin{array}{r}5971.50 \\
4\end{array}$ & 0 & $\begin{array}{r}320,00 \\
0\end{array}$ \\
\hline Benefits_d ${ }^{\mathrm{c}}$ & $\begin{array}{l}\text { Dummy=1 if employee perceives } \\
\text { one or more material benefits, } 0 \\
\text { otherwise }\end{array}$ & 17,872 & 0.281 & 0.449 & 0 & 1 \\
\hline Benefits $^{c}$ & No. of perceived material benefits & 17,872 & 0.410 & 0.793 & 0 & 6 \\
\hline $\mathrm{Meal}^{\mathrm{C}}$ & $\begin{array}{l}\text { Dummy }=1 \text { if employee gets meal as } \\
\text { material benefit, } \\
0 \text { otherwise }\end{array}$ & 17,872 & 0.166 & 0.372 & 0 & 1 \\
\hline $\mathrm{Car}^{\mathrm{c}}$ & $\begin{array}{l}\text { Dummy }=1 \text { if employee gets a car as } \\
\text { material benefit, } \\
0 \text { otherwise }\end{array}$ & 17,872 & 0.059 & 0.235 & 0 & 1 \\
\hline Phone $^{c}$ & $\begin{array}{l}\text { Dummy }=1 \text { if employee gets a phone } \\
\text { as material benefit, } 0 \text { otherwise }\end{array}$ & 17,872 & 0.064 & 0.246 & 0 & 1 \\
\hline Expenses $^{c}$ & $\begin{array}{l}\text { Dummy }=1 \text { if employee gets meal as } \\
\text { material benefit, } \\
0 \text { otherwise }\end{array}$ & 17,872 & 0.023 & 0.150 & 0 & 1 \\
\hline $\mathrm{PC}^{\mathrm{c}}$ & $\begin{array}{l}\text { Dummy }=1 \text { if employee gets a PC as } \\
\text { material benefit, } \\
0 \text { otherwise }\end{array}$ & 17,872 & 0.042 & 0.201 & 0 & 1 \\
\hline \multicolumn{7}{|c|}{ Personal Characteristics } \\
\hline Female & $\begin{array}{l}\text { Dummy=1 if employee is female, } 0 \\
\text { if male }\end{array}$ & 18,044 & 0.499 & 0.500 & 0 & 1 \\
\hline Age & Employee’s current wage & 17,866 & 42.315 & 10.765 & 17 & 65 \\
\hline Married & $\begin{array}{l}\text { Employee' current marital status, } \\
\text { Dummy= } 1 \text { if employee is married }\end{array}$ & 18,043 & 0.617 & 0.486 & 0 & 1 \\
\hline Child & $\begin{array}{l}\text { Dummy=1 if there is at least one } \\
\text { child in the household }\end{array}$ & 18,044 & 0.374 & 0.484 & 0 & 1 \\
\hline Risk & $\begin{array}{l}\text { Risk aversion with [0 extremely risk } \\
\text { averse to } 10 \text { risk seeking] }\end{array}$ & 17,972 & 4.771 & 2.178 & 0 & 10 \\
\hline Jobexp & $\begin{array}{l}\text { Working time in years (sum of full } \\
\text { time and } 1 / 2 \text { part-time job experiment) }\end{array}$ & 17,811 & 17.243 & 10.883 & 0 & 49.55 \\
\hline $\begin{array}{l}\text { Secondary general } \\
\text { school leaving } \\
\text { certificate }\end{array}$ & $\begin{array}{l}\text { Dummy= } 1 \text { if employee has a school } \\
\text { leaving certificate from a lower } \\
\text { secondary school } \\
\text { (Hauptschulabschluss), } 0 \text { otherwise }\end{array}$ & 17,215 & 0.273 & 0.446 & 0 & 1 \\
\hline
\end{tabular}




\begin{tabular}{llrrrrr}
\hline Variable & Description & Obs & Mean & Std. & Min & Max \\
\hline $\begin{array}{l}\text { Leaving certificate } \\
\text { from }\end{array}$ & $\begin{array}{l}\text { Dummy= 1 if employee has a } \\
\text { qualification for studies at a } \\
\text { faniversity of applied science }\end{array}$ & 17,215 & 0.064 & 0.244 & 0 & 1 \\
(Fachhochschulreife), 0 otherwise & & & & & \\
$\begin{array}{l}\text { Upper secondary } \\
\text { leaving certificate }\end{array}$ & $\begin{array}{l}\text { Dummy= 1 if employee has a } \\
\text { certificate from an upper secondary } \\
\text { school (Abitur), 0 otherwise }\end{array}$ & 17,215 & 0.214 & 0.410 & 0 & 1 \\
$\begin{array}{l}\text { Other school } \\
\text { leaving certificate }\end{array}$ & $\begin{array}{l}\text { Dummy= 1 if employee has another } \\
\text { school qualification, 0 otherwise }\end{array}$ & 17,215 & 0.064 & 0.246 & 0 & 1 \\
$\begin{array}{l}\text { Intermediate } \\
\text { school leaving } \\
\text { certificate }\end{array}$ & $\begin{array}{l}\text { Dummy= 1 if employee has a } \\
\text { certificate from an intermediate } \\
\text { secondary school }\end{array}$ & 17,215 & 0.385 & 0.487 & 0 & 1 \\
(Realschulabschluss), 0 otherwise & & & & & \\
(Reference Group) & & & & & \\
Education & Years of education & 17,475 & 12.403 & 2.554 & 7 & 18 \\
\hline
\end{tabular}

Descriptive data of variables used in further analyses; number of observations, mean, standard deviation, and the min and max are reported

${ }^{a}$ Agreement or disagreement with the following statements (Dummy variables): I receive the recognition I deserve from my superiors. (recog_superior); When I consider all my accomplishments and efforts, the recognition I've received seems fitting. (recog_performance; When I consider all my accomplishments and efforts, my chances of personal advancement seem fitting. (recog_career); When I think about all my accomplishments, my pay seems appropriate. (recog_wage)

${ }^{\mathrm{b}}$ Money equals the sum of the following additional gross payments: 13th, 14th month salary, additional Christmas bonus, vacation pay, profit-sharing bonuses or other bonuses

${ }^{\mathrm{c}}$ Do you receive other benefits from your employer besides your pay? (Dummy variables)

Discounted lunch in the company lunchroom or a meal stipend (meal); Company vehicle for private use (car); Cellular phone for personal use, or reimbursement of telephone costs (phone); Expense payments covering more than minimum costs (expenses); Personal computer or laptop for use at home (PC) or others 
Table A2: Prevalence of certain benefits (without job change)

\begin{tabular}{|c|c|c|c|c|c|c|}
\hline & (1) & $(2)$ & (3) & (4) & (5) & (6) \\
\hline & Benefits & Meal & Car & Phone & Expenses & PC \\
\hline \multirow[t]{2}{*}{ Sme } & $-0.123 * * *$ & $-0.992 * * *$ & $0.332 *$ & 0.009 & -0.128 & -0.135 \\
\hline & $(-6.94)$ & $(-12.32)$ & $(1.88)$ & $(0.09)$ & $(-1.05)$ & $(-1.13)$ \\
\hline \multirow[t]{2}{*}{ Food_industry } & $0.168^{* * *}$ & $1.610^{* * *}$ & & & & \\
\hline & $(4.24)$ & $(10.21)$ & & & & \\
\hline \multirow[t]{2}{*}{ Car_industry } & 0.061 & & 0.464 & & & \\
\hline & $(1.54)$ & & $(1.30)$ & & & \\
\hline \multirow[t]{2}{*}{ IT_industry } & $0.162^{* * *}$ & & & $0.462 * * *$ & & $0.549 * * *$ \\
\hline & $(5.35)$ & & & $(3.43)$ & & $(3.72)$ \\
\hline \multirow[t]{2}{*}{ Female } & $-0.089 * * *$ & -0.033 & $-1.296 * * *$ & $-0.823 * * *$ & $-0.231^{*}$ & -0.127 \\
\hline & $(-4.11)$ & $(-0.36)$ & $(-5.05)$ & $(-6.30)$ & $(-1.68)$ & $(-0.96)$ \\
\hline \multirow[t]{2}{*}{ Age } & 0.001 & 0.006 & -0.002 & 0.009 & 0.018 & 0.037 \\
\hline & $(0.19)$ & $(0.21)$ & $(-0.03)$ & $(0.22)$ & $(0.41)$ & $(0.78)$ \\
\hline \multirow[t]{2}{*}{ Age $^{2}$} & -0.000 & -0.000 & 0.000 & -0.000 & -0.000 & -0.001 \\
\hline & $(-0.09)$ & $(-1.10)$ & $(0.21)$ & $(-0.19)$ & $(-0.40)$ & $(-1.02)$ \\
\hline \multirow[t]{2}{*}{ Married } & -0.014 & $-0.306 * * *$ & 0.138 & -0.010 & 0.020 & -0.005 \\
\hline & $(-0.70)$ & $(-3.71)$ & $(0.79)$ & $(-0.09)$ & $(0.16)$ & $(-0.04)$ \\
\hline \multirow[t]{2}{*}{ Child } & 0.001 & -0.086 & 0.180 & -0.021 & -0.193 & 0.076 \\
\hline & $(0.04)$ & $(-1.06)$ & $(1.05)$ & $(-0.20)$ & $(-1.59)$ & $(0.64)$ \\
\hline \multirow[t]{2}{*}{ Risk } & $0.009 * * *$ & 0.010 & 0.038 & $0.054 * * *$ & $0.077 * * *$ & $0.072 * * *$ \\
\hline & $(2.82)$ & $(0.70)$ & $(1.31)$ & $(2.74)$ & (3.18) & (3.11) \\
\hline \multirow[t]{2}{*}{ Prom } & $0.002 * * *$ & $0.004 * *$ & $0.013^{* * *}$ & $0.007 * * *$ & $0.006 * * *$ & $0.006^{* * *}$ \\
\hline & $(6.35)$ & $(2.32)$ & (3.93) & $(3.51)$ & $(3.02)$ & $(3.04)$ \\
\hline \multirow[t]{2}{*}{ Tenure } & $-0.004 * * *$ & 0.001 & $-0.029 * * *$ & -0.008 & $-0.024 * * *$ & $-0.014 * *$ \\
\hline & $(-3.98)$ & $(0.11)$ & $(-3.07)$ & $(-1.40)$ & $(-3.42)$ & $(-2.11)$ \\
\hline \multirow[t]{2}{*}{ Jobexp } & 0.000 & 0.005 & 0.028 & 0.010 & -0.003 & 0.021 \\
\hline & $(0.02)$ & $(0.58)$ & $(1.30)$ & $(0.79)$ & $(-0.23)$ & $(1.46)$ \\
\hline \multirow{2}{*}{$\begin{array}{l}\text { Secondary general school leaving } \\
\text { certificate }\end{array}$} & $-0.058 * *$ & -0.144 & -0.032 & -0.024 & 0.019 & $-0.448 * *$ \\
\hline & $(-2.50)$ & $(-1.44)$ & $(-0.14)$ & $(-0.18)$ & $(0.13)$ & $(-2.54)$ \\
\hline Leaving certificate from & $0.064 *$ & 0.067 & $0.487 *$ & -0.002 & 0.033 & 0.070 \\
\hline \multirow{3}{*}{$\begin{array}{l}\text { Fachoberstufe } \\
\text { Upper secondary leaving } \\
\text { certificate }\end{array}$} & $(1.72)$ & $(0.45)$ & $(1.71)$ & $(-0.01)$ & $(0.17)$ & $(0.37)$ \\
\hline & $0.075^{* * *}$ & 0.156 & 0.358 & 0.006 & -0.044 & $0.262 *$ \\
\hline & $(2.92)$ & $(1.48)$ & $(1.47)$ & $(0.05)$ & $(-0.29)$ & $(1.83)$ \\
\hline \multirow[t]{2}{*}{ Other school leaving certificate } & $-0.129 * * *$ & -0.173 & $-1.729 * * *$ & $-0.995 * * *$ & $-0.533^{*}$ & $-0.687 * *$ \\
\hline & $(-3.36)$ & $(-1.05)$ & $(-3.66)$ & $(-3.19)$ & $(-1.66)$ & $(-1.98)$ \\
\hline \multirow[t]{2}{*}{ Part-time } & $0.068 * *$ & -0.112 & 0.160 & 0.075 & -0.251 & 0.209 \\
\hline & $(2.52)$ & $(-0.91)$ & $(0.53)$ & $(0.38)$ & $(-0.95)$ & $(1.03)$ \\
\hline Overtime & $0.014 * * *$ & 0.008 & $0.066^{* * *}$ & $0.044 * * *$ & $0.027 * * *$ & $0.036^{* * *}$ \\
\hline & $(7.17)$ & $(0.97)$ & $(5.01)$ & $(5.03)$ & $(2.62)$ & $(3.49)$ \\
\hline Blue-collar & $-0.097 * * *$ & $-0.204 * *$ & $-1.082 * * *$ & $-0.526 * * *$ & 0.151 & $-0.776 * * *$ \\
\hline & $(-4.65)$ & $(-2.19)$ & $(-4.54)$ & $(-3.89)$ & $(1.01)$ & $(-3.99)$ \\
\hline Manager & $0.221^{* * *}$ & -0.015 & $1.127 * * *$ & $0.700 * * *$ & 0.164 & $0.777 * * *$ \\
\hline & $(9.59)$ & $(-0.16)$ & $(5.72)$ & $(5.75)$ & $(1.13)$ & $(5.78)$ \\
\hline $\ln$ (income) & $0.306 * * *$ & $0.651 * * *$ & $1.782 * * *$ & $1.221 * * *$ & $1.055^{* * *}$ & $1.003^{* * *}$ \\
\hline & $(14.81)$ & $(6.72)$ & $(9.29)$ & $(9.27)$ & $(6.49)$ & $(7.08)$ \\
\hline Money_d & $0.050 * * *$ & $0.361 * * *$ & 0.007 & 0.080 & $0.254^{*}$ & 0.059 \\
\hline & $(2.72)$ & (3.98) & $(0.05)$ & $(0.76)$ & (1.87) & $(0.47)$ \\
\hline Western & $0.122 * * *$ & $0.601 * * *$ & -0.068 & 0.128 & 0.031 & $0.467 * * *$ \\
\hline & $(5.49)$ & $(5.95)$ & $(-0.32)$ & $(1.04)$ & $(0.22)$ & (3.18) \\
\hline Works council & $-0.066 * * *$ & $0.910^{* * *}$ & $-1.779 * * *$ & $-0.833^{* * *}$ & $-0.338^{* *}$ & $-0.304 * *$ \\
\hline & $(-3.20)$ & $(9.00)$ & $(-8.02)$ & $(-6.80)$ & $(-2.57)$ & $(-2.27)$ \\
\hline Year dummy (2006) & 0.008 & $0.146^{* * *}$ & -0.053 & -0.018 & 0.041 & -0.119 \\
\hline & $(0.82)$ & $(3.10)$ & $(-0.59)$ & $(-0.29)$ & $(0.49)$ & $(-1.59)$ \\
\hline lnsig2u & & $1.079 * * *$ & $2.093^{* * *}$ & $0.991^{* * *}$ & $0.468 * *$ & $0.915^{* * *}$ \\
\hline _cons & & $(11.57)$ & $(15.12)$ & $(7.08)$ & $(2.09)$ & $(5.58)$ \\
\hline $\mathrm{N}$ & 10970 & 10970 & 10970 & 10970 & 10970 & 10970 \\
\hline
\end{tabular}

Random Effects (1) Probit regression (2-7), t statistics in parentheses, * significant at 10\%; ** significant at 5\%; *** significant at 1\%; dependent variable is (1) the number of received benefits/ (2-7) whether an employee receives the benefit or not, constants included but not reported (Analysis of the GSOEP 2006, 2008) 
Table A3: Impact of monetary and material incentives on the feeling of being recognized

\begin{tabular}{|c|c|c|c|c|c|c|c|c|}
\hline \multirow[b]{2}{*}{ Meal } & \multicolumn{2}{|c|}{$\begin{array}{c}\text { (1) } \\
\text { recog_superior }\end{array}$} & \multicolumn{2}{|c|}{$\begin{array}{c}\text { (2) } \\
\text { recog_performance }\end{array}$} & \multicolumn{2}{|c|}{$\begin{array}{c}\text { (3) } \\
\text { recog_career }\end{array}$} & \multicolumn{2}{|c|}{$\begin{array}{c}(4) \\
\text { recog_wage }\end{array}$} \\
\hline & $0.089 * *$ & $(1.97)$ & 0.064 & $(1.43)$ & $0.092 * *$ & (2.07) & 0.057 & $(1.28)$ \\
\hline Car & -0.037 & $(-0.47)$ & -0.039 & $(-0.50)$ & $0.172^{* *}$ & (2.14) & 0.092 & (1.14) \\
\hline Phone & -0.025 & $(-0.32)$ & $0.142 *$ & $(1.85)$ & 0.117 & (1.50) & 0.075 & $(0.98)$ \\
\hline Expenses & 0.063 & $(0.57)$ & -0.114 & $(-1.06)$ & 0.166 & (1.48) & 0.018 & $(0.17)$ \\
\hline PC & 0.082 & $(0.91)$ & 0.025 & $(0.28)$ & 0.147 & $(1.62)$ & $-0.150^{*}$ & $(-1.68)$ \\
\hline $\ln$ (income) & -0.026 & $(-0.55)$ & 0.011 & $(0.23)$ & $0.112^{* *}$ & (2.45) & $0.473^{* * *}$ & $(9.42)$ \\
\hline Money & 0.000 & $(1.48)$ & $0.000 * *$ & (2.49) & 0.000 & (1.27) & $0.000 * *$ & (2.46) \\
\hline Western & $0.084^{* *}$ & (2.11) & 0.054 & (1.35) & 0.055 & (1.38) & $0.172 * * *$ & (4.18) \\
\hline Works council & -0.010 & $(-0.23)$ & 0.013 & $(0.31)$ & $-0.088 * *$ & $(-2.13)$ & 0.022 & $(0.52)$ \\
\hline Sme & 0.005 & $(0.13)$ & -0.018 & $(-0.44)$ & -0.006 & $(-0.16)$ & -0.063 & $(-1.56)$ \\
\hline food_industry & $-0.137 *$ & $(-1.69)$ & -0.092 & $(-1.13)$ & -0.073 & $(-0.91)$ & $-0.150 *$ & $(-1.78)$ \\
\hline car_industry & -0.019 & $(-0.22)$ & -0.091 & $(-1.05)$ & -0.094 & $(-1.08)$ & 0.071 & $(0.82)$ \\
\hline IT_industry & 0.034 & $(0.53)$ & 0.007 & $(0.11)$ & -0.018 & $(-0.28)$ & $0.146^{* *}$ & $(2.26)$ \\
\hline Blue-collar & -0.063 & $(-1.44)$ & 0.026 & $(0.59)$ & -0.010 & $(-0.22)$ & -0.013 & $(-0.30)$ \\
\hline Manager & $0.219 * * *$ & $(4.03)$ & $0.164 * * *$ & (3.04) & $0.186^{* * *}$ & (3.48) & 0.040 & $(0.75)$ \\
\hline Female & -0.037 & $(-0.89)$ & -0.028 & $(-0.68)$ & 0.039 & $(0.96)$ & 0.006 & $(0.15)$ \\
\hline Age & $-0.039 * * *$ & $(-2.99)$ & $-0.046^{* * *}$ & $(-3.56)$ & $-0.059 * * *$ & $(-4.61)$ & $-0.042 * * *$ & $(-3.26)$ \\
\hline Age $^{2}$ & $0.000 * * *$ & $(2.72)$ & $0.001^{* * *}$ & $(3.45)$ & $0.001 * * *$ & $(4.09)$ & $0.000 * * *$ & $(2.98)$ \\
\hline Married & 0.025 & $(0.66)$ & 0.048 & (1.27) & 0.033 & $(0.88)$ & 0.058 & $(1.54)$ \\
\hline Tenure & $-0.004 * *$ & $(-1.97)$ & $-0.007 * * *$ & $(-3.17)$ & -0.001 & $(-0.32)$ & 0.001 & $(0.42)$ \\
\hline Education (years) & $-0.024 * * *$ & $(-2.84)$ & $-0.030 * * *$ & $(-3.48)$ & $-0.031^{* * *}$ & $(-3.61)$ & -0.012 & $(-1.39)$ \\
\hline Overtime & $-0.012 * * *$ & $(-2.68)$ & $-0.022 * * *$ & $(-5.02)$ & $-0.012 * * *$ & $(-2.62)$ & $-0.040 * * *$ & $(-8.13)$ \\
\hline Part-time & $0.337 * * *$ & $(9.48)$ & $0.326 * * *$ & $(9.19)$ & $0.319 * * *$ & $(9.12)$ & $0.262 * * *$ & $(7.54)$ \\
\hline Job security & 0.084 & $(1.53)$ & $0.166^{* * *}$ & (3.05) & $0.107 * *$ & $(1.98)$ & $0.497 * * *$ & $(9.04)$ \\
\hline$N$ & 6420 & & 6420 & & 6420 & & 6420 & \\
\hline $\begin{array}{l}\text { Probit regression, ro } \\
\text { dependent variables } \\
\text { recognition I deserv } \\
\text { recognition I've rece } \\
\text { chances of personal }\end{array}$ & 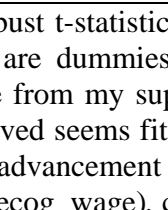 & 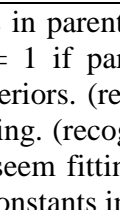 & 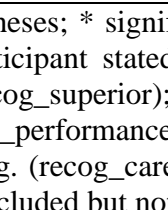 & 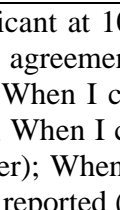 & (2) & 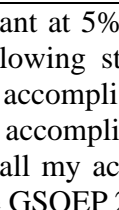 & sig & $\begin{array}{l}\text { t at } 1 \% \text {, } \\
\text { ceive the } \\
\text { forts, the } \\
\text { forts, my } \\
\text { my pay }\end{array}$ \\
\hline
\end{tabular}


Table A4: Impact of monetary and material incentives on work and wage satisfaction

\begin{tabular}{|c|c|c|c|c|}
\hline & $\begin{array}{c}(1) \\
\text { satwork }\end{array}$ & $\begin{array}{c}(2) \\
\text { satwork }\end{array}$ & $\begin{array}{c}(3) \\
\text { satwage }\end{array}$ & $\begin{array}{c}\text { (4) } \\
\text { satwage }\end{array}$ \\
\hline Benefit_d & $\begin{array}{c}0.262 * * * \\
(2.61)\end{array}$ & $\begin{array}{c}0.247 * * \\
(2.15)\end{array}$ & $\begin{array}{c}0.184^{* *} \\
(2.01)\end{array}$ & $\begin{array}{l}0.166 \\
(1.59)\end{array}$ \\
\hline Money & $\begin{array}{l}-0.000 \\
(-0.89)\end{array}$ & $\begin{array}{l}-0.000 \\
(-0.42)\end{array}$ & $\begin{array}{l}0.000 \\
(1.56)\end{array}$ & $\begin{array}{l}0.000 \\
(1.63)\end{array}$ \\
\hline $\ln ($ income) & $\begin{array}{c}0.439 * * \\
(2.56)\end{array}$ & $\begin{array}{c}0.767 * * * \\
(2.80)\end{array}$ & $\begin{array}{c}1.075^{* * *} \\
(7.23)\end{array}$ & $\begin{array}{c}1.362 * * * \\
(5.90)\end{array}$ \\
\hline $\begin{array}{l}\text { Job } \\
\text { characteristics }^{\text {a }}\end{array}$ & - & Yes & - & Yes \\
\hline $\begin{array}{l}\text { Personal } \\
\text { characteristics b }\end{array}$ & - & Yes & - & Yes \\
\hline $\begin{array}{l}\text { Organizational } \\
\text { characteristics }^{\mathrm{c}}\end{array}$ & - & Yes & - & Yes \\
\hline$N$ & 15423 & 12742 & 15571 & 12774 \\
\hline$R^{2}$ & 0.009 & 0.041 & 0.038 & 0.044 \\
\hline
\end{tabular}

Fixed Effects Regression, robust t-statistics in parentheses; * significant at $10 \%$; ** significant at $5 \%$; *** significant at $1 \%$, dependent variables are the degree of satisfaction with work (satwork) and wage (satwage) on a scale from 0 (unsatisfied) to 10 (satisfied), constants are included but not reported

a tenure, job security, overtime (except for models 5 and 6), part-time, blue-collar, manager

${ }^{\mathrm{b}}$ age, age ${ }^{2}$, education

${ }^{\mathrm{c}}$ western, sme, food_industry, car_industry, IT_industry, job change 